\title{
ANALISIS KESESUAIAN PERAIRAN BAGI KEGIATAN WISATA BAHARI SNORKLING DAN SELAM DI PERAIRAN PULAU NUSALAUT KABUPATEN MALUKU TENGAH
}

\author{
ANALYSIS OF WATERS SUITABILITY FOR SNORKELING AND DIVING \\ MARINE TOURISM IN WATERS OF NUSALAUT ISLAND, \\ CENTRE MALUKU REGENCY
}

\author{
Terry Indrabudi*, Arif Seno Adji, Widhya Nugroho Satrioajie dan Robert Alik \\ Pusat Penelitian Laut Dalam-LIPI, Ambon, 97233, Indonesia \\ *E-mail: terr001@lipi.go.id
}

\begin{abstract}
The Maluku Islands have the potentials of marine resources, including marine tourism which is currently a priority for the government to develop. But in reality, the development of marine tourism in Maluku faces various obstacles, such as determining the appropriate location to be a tourist destination. This study intends to see the suitability of the tourism area, especially snorkeling and diving in Nusalaut Island. Sampling was carried out in 2014 and 2015 in 6 different locations. Retrieval of coral data using the Line Intercept Transect method and analyzed using the "Life Form Program". Observation of reef fish was done by Underwater Visual Census and transects. Environmental parameters are taken by direct measurement in the field. Coral reefs are categorized as "Good" and "Very Good". A total of 217 types of rock corals belonging to 52 genera from 16 families occupy reef flats. Reef fish biodiversity is in a fairly good condition with a diversity index ranging from 3,046-4,089. There are at least 2,838 individual reef fishes from 25 families and 170 species. Waters' transparency ranges from 8-12 $\mathrm{m}$ with a current velocity between 1.6-18.5 m/s. Based on the results of the tourism suitability analysis, all research locations are categorized as "Very Appropriate" to be used as a snorkeling and diving tourist destination with a Tourism Suitability Index between $81.25-95.83 \%$.
\end{abstract}

Keywords: Central Maluku, marine tourism, Nusalaut Island, waters suitability

\begin{abstract}
ABSTRAK
Maluku memiliki sumberdaya laut yang sangat besar, baik sumberdaya hayati maupun nir-hayati termasuk potensi wisata bahari yang menjadi prioritas pemerintah untuk dikembangkan. Namun pada kenyataannya, perkembangan wisata bahari di Maluku masih menghadapi berbagai kendala, yaitu menentukan lokasi yang layak untuk dijadikan tujuan wisata. Penelitian ini bermaksud untuk melihat tingkat kesesuaian wisata khususnya wisata snorkling dan selam di perairan Pulau Nusalaut. Pengambilan sampel dilakukan pada tahun 2014 dan 2015 di 6 (enam) lokasi yang berbeda. Pengambilan data karang menggunakan metoda LIT (Line Intecept Trancect) dan dianalisis menggunakan "Life Form Program". Pengamatan ikan karang dilakukan dengan Underwater Visual Census (UVC) dan transek. Parameter lingkungan diambil dengan cara pengukuran langsung dilapangan. Terumbu karang dikategorikan dalam kondisi "Baik" dan "Sangat Baik" dengan persentase tutupan karang antara 58,54-77\%. Sebanyak 217 jenis karang batu yang termasuk ke dalam 52 genera dari 16 famili menempati rataan terumbu. Keanekaragaman ikan karang berada pada kondisi yang cukup baik dengan indeks keanekaragaman berkisar antara 3,05-4,09. Setidaknya terdapat 2.838 individu ikan karang dari 25 famili dan 170 jenis, terbagi dalam kelompok ikan indikator sebanyak $6 \%$, ikan mayor $67 \%$ dan ikan target $27 \%$. Kecerahan perairan berkisar antara 8-12 m dengan kecepatan arus antara 1,6-18,5 m/s. Berdasarkan hasil analisis kesesuaian wisata, seluruh lokasi penelitian dikategorikan "Sangat Sesuai" untuk dijadikan tujuan wisata snorkling maupun selam dengan Indeks Kesesuaian Wisata antara 81,25-95,83\%.
\end{abstract}

Kata kunci: kesesuaian perairan, Maluku Tengah, Pulau Nusalaut, wisata bahari 


\section{PENDAHULUAN}

Terumbu karang mempunyai peranan yang sangat penting bagi kehidupan manusia dan ekosistem pesisir dan laut. Kurang lebih 0,1-1\% dari luas lautan di dunia ditumbuhi oleh terumbu karang (Hughes et al., 2003; Spalding and Grenfell, 1997; Smith, 1978; and Copper, 1994) dan menopang kehidupan sekitar 1/3 spesies ikan di dunia (Newton et al., 2007). Sekitar 10\% ikan konsumsi ditemukan di daerah terumbu karang.

Selain itu, terumbu karang memberikan kontribusi yang cukup besar pada sektor jasa seperti industri pariwisata, restoran, perlindungan kawasan pesisir maupun keuntungan budaya (Ahmed et al., 2007; Smith, 1978; Kühlmann, 1988; Spurgeon, 1992; Peterson and Lubchenco, 1997). Bertels et al. (2008) menyebutkan terumbu karang memiliki peran yang sangat penting dalam ekosistem pesisir. Tidak hanya menawarkan keanekaragaman jenis saja, tetapi mempunyai sumberdaya sosialekonomi bagi masyarakat pesisir. Selanjutnya Suharsono (2008) menambahkan terumbu karang juga dapat berfungsi sebagai daerah wisata, baik wisata pantai maupun bawah laut.

Nybakken (1992) terumbu karang merupakan ekosistem paling indah dalam hal warna dan bentuk serta desainnya, sangat kaya akan keanekaragaman jenis biota yang hidup di dalamnya serta dapat meningkatkan taraf hidup masyarakat sebagai daerah pariwisata bahari. Menurut Wilkinson (2000), terumbu karang merupakan daerah tangkapan ikan utama serta memiliki potensi pariwisata bahari yang sangat tinggi, sehingga akan memiliki kontribusi yang nyata terhadap pe-nambahan pendapatan daerah. Indonesia mendapatkan keuntungan dari terumbu karang dalam sektor wisata bahari diperkirakan US $\$ 1,000,000 / \mathrm{km}^{2} /$ tahun (UNEP 2006, dalam Susanto et al. 2015).

Hasil inventarisasi Dinas Kebudayaan dan Pariwisata Provinsi Maluku tahun 2011 diketahui terdapat 302 potensi pariwisata yang terdiri dari wisata sejarah $(20 \%)$, wisata budaya $(15,2 \%)$, wisata alam $(28 \%)$, wisata bahari $(36,6 \%)$, dan wisata buatan $(1,8 \%)$. Hal tersebut menunjukan bahwa Provinsi Maluku memiliki potensi yang sangat besar dalam bidang wisata bahari. Perkembangan sektor wisata bahari di Provinsi Maluku diperkuat dengan adanya Perda Provinsi Maluku No.10 Tahun 2013 tentang Pengelolaan Wilayah Pesisir dan Pulau-Pulau Kecil yang menyatakan bahwa pemanfaatan pulau-pulau kecil dan sekitarnya diprioritaskan salah satunya menjadi kawasan pariwisata. Begitu juga dengan Kabupaten Maluku Tengah sangat mendukung Pulau Nusalaut untuk dikembangkan menjadi kawasan pariwisata, dengan diterbitkannya Perda Kabupaten Maluku Tengah No. 1 Tahun 2012 Tentang RTRW Kabupaten Maluku Tengah yang menyatakan bahwa wilayah Pulau Nusalaut masuk dalam Kecamatan Saparua yang merupakan kawasan pengembangan Wisata Bahari, Budaya dan Sejarah

Terdapat berbagai kendala dalam pengembangan sektor wisata bahari di Provinsi Maluku dan Kabupaten Maluku Tengah pada khususnya. Sarana prasarana wisata dan promosi merupakan kendala yang menghambat perkembangan sektor wisata bahari di daerah ini. Selain itu juga, masih minimnya kajian dan penelitian mengenai lokasi-lokasi yang layak untuk dikembangkan menjadi kawasan wisata bahari. Untuk itu penelitian ini bertujuan untuk melihat kesesuaian kawasan wisata bahari khususnya untuk kegiatan snorkling dan selam di daerah Pulau Nusalaut.

\section{METODE PENELITIAN}

\subsection{Waktu dan Tempat Penelitian}

Penelitian dilakukan di wilayah perairan Pulau Nusalaut Kabupaten Maluku Tengah Provinsi Maluku. Pengambilan data terumbu karang, ikan karang, kecepatan arus, lebar hamparan, kedalaman dan kecerahan perairan dilakukan pada bulan April 2014 di 
6 (enam) stasiun yaitu: Negeri Ameth, Negeri Akoon, Negeri Nalahia, Negeri Sila, Negeri Titawaai dan Negeri Abubu.

\subsection{Bahan dan Data}

Pengukuran arah dan kecepatan arus dilakukan dengan menggunakan Electromagnet Current Meter, ALEC, Model $A E M-H R$ di 11 (sebelas) stasiun pengamatan (untuk lapisan permukaan s/d kedalaman 50 m) dilakukan pada bulan April 2015.

Pengambilan data terumbu karang menggunakan metode LIT (Line Intercept Transect) berdasarkan LIPI; COREMAP; CRITC (2006) untuk menggambarkan struktur komunitas karang dengan melihat tutupan karang hidup, karang mati, bentuk substrat (pasir dan/atau lumpur), alga, dan keberadaan biota bentik lainnya. Spesifikasi karang yang dijumpai dicatat dalam bentuk pertumbuhan (lifeform), dan pengukuran dilakukan dengan tingkat ketelitian mendekati sentimeter.

Metode yang digunakan dalam kegiatan penelitian ikan karang megikuti metode Dartnall and Jones (1986). Pengamatan ikan karang dilakukan dengan Underwater Visual Census (UVC) dan transek. Ikan-ikan yang dijumpai diamati jenisnya dan dicacah sepanjang garis transek. Untuk mengoptimalkan hasil pengamatan dilakukan dengan pengambilan foto dan video bawah air. Reidentifikasi ikan jenisjenis tertentu melalui foto atau video dilakukan dengan mengidentifikasi gambar (Allen et al., 2003).

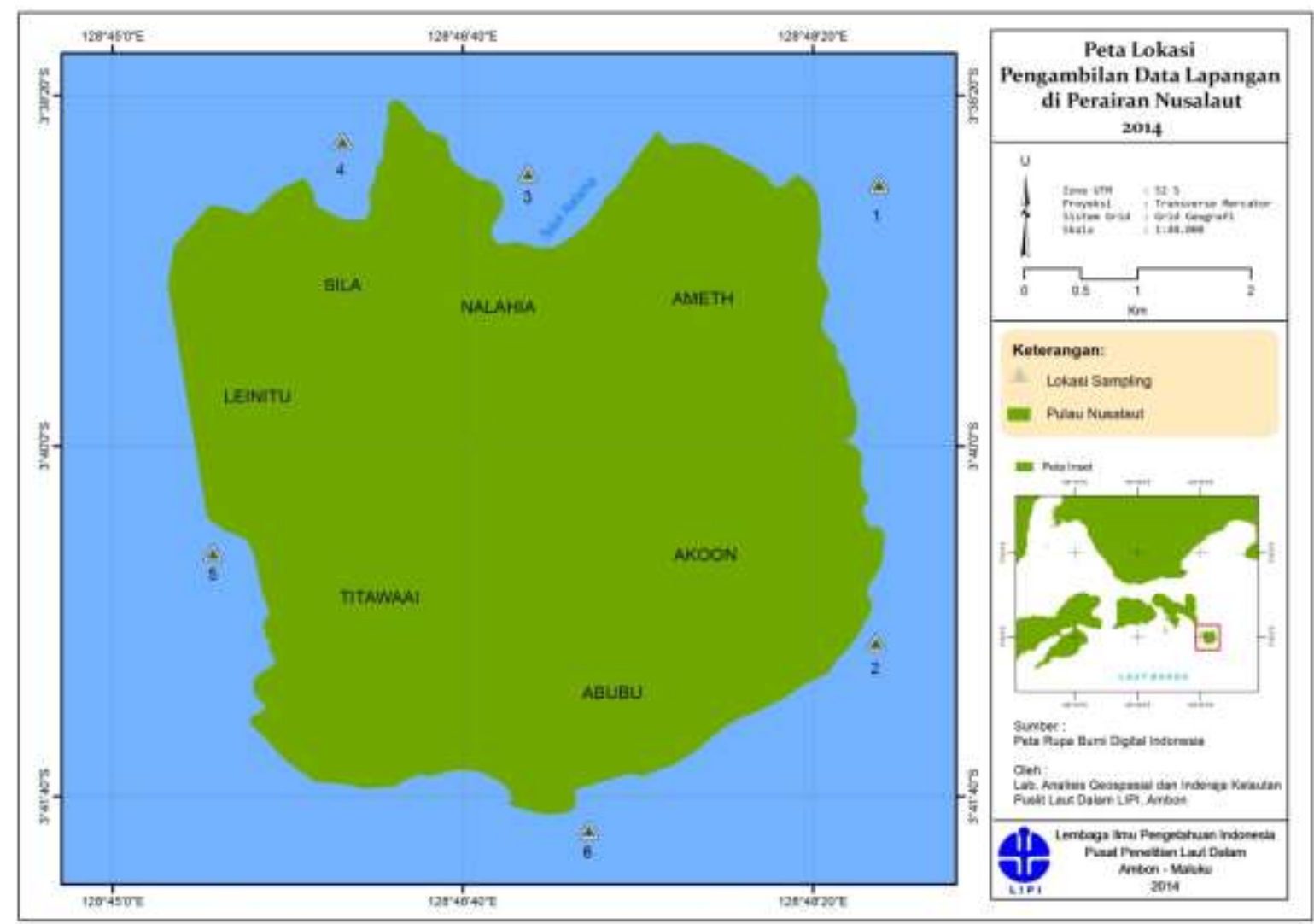

Gambar 1. Stasiun penelitian di Pulau Nusalaut. 


\subsection{Analisa Data}

Kondisi karang batu dinilai dari hasil analisis menggunakan kriteria yang dikemukakan oleh Wilkinson et al. (1992), yaitu ada 4 kategori sebagai berikut:
Indeks keseragaman (equalibility) (e) menunjukkan kelimpahan yang hampir seragam dan merata antar jenis (Odum, 1983). Untuk perlakuan indeks kesamaan mengacu pada studi dari Alatalo (1981),

- Kategori 1 (Sangat rusak), persen penutupxaitu:

karang batu antara 0-24,9\%.

- Kategori 2 (Rusak), persen penutupan karang batu antara 25-49,9\%.

- Kategori 3 (Baik), persen penutupan karang batu antara 50-74,9\%.

- Kategori 4 (Sangat baik), persen penutupan karang batu antara $75-100 \%$.

Jenis-jenis karang batu yang tidak teridentifikasi in-situ diambil contohnya kemudian diidentifikasi di laboratorium menurut buku petunjuk yang dikemukakan oleh Veron (1986) dan Suharsono (2008), serta Coral ID.

Struktur komunitas ikan dianalisa dengan melakukan penghitungan pada beberapa variabel antara lain indeks keanekaragaman (H'), keseragaman (e), dan indeks dominansi (D). Tingginya tingkat keanekaragaman menunjukkan individu berasal dari genus atau spesies yang berbedabeda. Sebaliknya nilai tersebut rendah ketika semua individu berasal dari satu genus atau beberapa spesies saja (Odum, 1983). Adapun indeks keanekaragaman Shannon (H') menurut Shannon and Weaver (1949) dalam Odum (1983), dihitung menggunakan formula:

$\mathrm{H}^{\prime}=-\sum\left(\mathrm{n}_{\mathrm{i}} / \mathrm{N}\right) \ln \left(\mathrm{n}_{\mathrm{i}} / \mathrm{N}\right)$

Keterangan:

$\mathrm{n}_{\mathrm{i}}=$ Jumlah individu setiap jenis

$\mathrm{N}=$ Jumlah individu seluruh jenis

Nilai indeks keanekaragaman Shannon dikategorikan atas nilai-nilai sebagai berikut, yaitu apabila nilai $\mathrm{H}^{\prime} \leq 2$ maka keanekaragaman rendah, nilai $2<\mathrm{H}^{\prime} \leq$ 3 maka tingkat keanekaragaman sedang, dan apabila nilai $\mathrm{H}^{\prime} \geq 3$ maka tingkat keanekaragaman tinggi.

$\mathrm{e}=\mathrm{H}^{\prime} / \ln \mathrm{S}$

Keterangan:

$\mathrm{S}=$ Jumlah jenis

Adapun kategori nilai indeks keseragaman (e) yaitu apabila nilai $0,00<\mathrm{e} \leq 0,50$ komunitas berada pada kondisi tertekan, 0,50 $<\mathrm{e} \leq 0,75$ komunitas berada pada kondisi labil dan $0,75<\mathrm{e} \leq 1,00$ komunitas berada pada kondisi stabil.

Indeks dominansi Simpson mendeskripsikan dominasi organisme dalam suatu komunitas ekologi bilamana terdapat jenis yang lebih banyak pada saat pengambilan data.

$\mathrm{D}=\sum\left(\mathrm{n}_{\mathrm{i}} / \mathrm{N}\right)^{2}$

\section{Keterangan:}

Dominansi (D) berada pada kategori sedang ketika $0,00<\mathrm{D} \leq 0,50$, sedangkan kategori sedang untuk nilai $0,50<\mathrm{D} \leq 0,75$. Dominansi tinggi ditunjukkan pada nilai 0,75 $<\mathrm{D} \leq 1,00$.

Menurut Yulianda et al. (2010) kesesuaian wisata snorkling mempertimbangkan 7 (tujuh) parameter kesesuaian (Tabel 1), sedangkan kesesuaian wisata selam mempertimbangkan 6 (enam) parameter kesesuaian (Tabel 2). Untuk menghitung Indeks Kesesuaian Wisata (IKW) dapat menggunakan rumus :

$I K W=\sum\left[\frac{N_{i}}{N_{\text {maks }}}\right] \times 100 \%$

Keterangan:

$\mathrm{N}_{\mathrm{i}}$ : Nilai parameter ke-i (bobot $\mathrm{x}$ skor) dan $\mathrm{N}_{\text {maks: }}$ nilai maksimum dari suatu kategori 
wisata. Kesesuaian kawasan wisata (60-79\%), S3= Sesuai Bersayarat (30-59\%) dikategorikan dalam empat kategori, yaitu: dan $\mathrm{N}=$ Tidak Sesuai $(<30 \%)$. S1= Sangat Sesuai $(80-100 \%)$, S2= Sesuai

Tabel 1. Matriks kesesuaian wisata snorkling.

\begin{tabular}{|c|c|c|c|c|c|c|c|c|c|c|}
\hline \multirow[b]{2}{*}{ No } & \multirow[b]{2}{*}{ Parameter } & \multirow[b]{2}{*}{ Bobot } & \multicolumn{2}{|l|}{ S1 } & \multicolumn{2}{|l|}{ S2 } & \multicolumn{2}{|l|}{ S3 } & \multicolumn{2}{|l|}{$\mathrm{N}$} \\
\hline & & & $\begin{array}{c}\text { Standar } \\
\text { Parameter }\end{array}$ & Skor & $\begin{array}{c}\text { Standar } \\
\text { Parameter }\end{array}$ & Skor & $\begin{array}{c}\text { Standar } \\
\text { Parameter }\end{array}$ & Skor & $\begin{array}{c}\text { Standar } \\
\text { Parameter }\end{array}$ & Skor \\
\hline 1 & $\begin{array}{l}\text { Kecerahan } \\
\text { perairan }(\mathrm{m})\end{array}$ & 5 & $>10$ & 4 & $>5-10$ & 3 & $3-5$ & 2 & $<2$ & 1 \\
\hline 2 & $\begin{array}{l}\text { Tutupan } \\
\text { komunitas } \\
\text { karang }(\%)\end{array}$ & 5 & $>75$ & 4 & $>50-75$ & 3 & $25-50$ & 2 & $<25$ & 1 \\
\hline 3 & $\begin{array}{l}\text { Jenis life- } \\
\text { form }\end{array}$ & 4 & $>12$ & 4 & $<7-12$ & 3 & $4-7$ & 2 & $<4$ & 1 \\
\hline 4 & $\begin{array}{l}\text { Jenis ikan } \\
\text { karang }\end{array}$ & 4 & $>50$ & 4 & $30-50$ & 3 & $10->30$ & 2 & $<10$ & 1 \\
\hline 5 & $\begin{array}{l}\text { Kecepatan } \\
\text { arus } \\
(\mathrm{cm} / \mathrm{det})\end{array}$ & 3 & $0-15$ & 4 & $>15-30$ & 3 & $>30-50$ & 2 & $>50$ & 1 \\
\hline 6 & $\begin{array}{l}\text { Kedalaman } \\
\text { terumbu } \\
\text { karang (m) }\end{array}$ & 3 & $1-3$ & 4 & $>3-6$ & 3 & $>6-10$ & 2 & $>10,<1$ & 1 \\
\hline 7 & $\begin{array}{l}\text { Lebar } \\
\text { hamparan } \\
\text { datar karang } \\
\text { (m) }\end{array}$ & 3 & $>500$ & 4 & $\begin{array}{c}>100- \\
500\end{array}$ & 3 & $20-100$ & 2 & $<20$ & 1 \\
\hline
\end{tabular}

Sumber : Yulianda et al., (2010)

Tabel 2. Matriks kesesuaian wisata selam.

\begin{tabular}{|c|c|c|c|c|c|c|c|c|c|c|}
\hline \multirow[b]{2}{*}{ No } & \multirow[b]{2}{*}{ Parameter } & \multirow[b]{2}{*}{ Bobot } & \multicolumn{2}{|l|}{$\mathrm{S} 1$} & \multicolumn{2}{|l|}{ S2 } & \multicolumn{2}{|l|}{ S3 } & \multicolumn{2}{|l|}{$\mathrm{N}$} \\
\hline & & & $\begin{array}{c}\text { Standar } \\
\text { Parameter }\end{array}$ & Skor & $\begin{array}{c}\text { Standar } \\
\text { Parameter }\end{array}$ & Skor & $\begin{array}{c}\text { Standar } \\
\text { Parameter }\end{array}$ & Skor & $\begin{array}{c}\text { Standar } \\
\text { Parameter }\end{array}$ & Skor \\
\hline 1 & $\begin{array}{l}\text { Kecerahan } \\
\text { perairan }(\mathrm{m})\end{array}$ & 5 & $>10$ & 4 & $>5-10$ & 3 & $3-5$ & 2 & $<2$ & 1 \\
\hline 2 & $\begin{array}{l}\text { Tutupan } \\
\text { komunitas } \\
\text { karang }(\%)\end{array}$ & 5 & $>75$ & 4 & $>50-75$ & 3 & $25-50$ & 2 & $<25$ & 1 \\
\hline 3 & $\begin{array}{l}\text { Jenis life- } \\
\text { form }\end{array}$ & 4 & $>12$ & 4 & $<7-12$ & 3 & $4-7$ & 2 & $<4$ & 1 \\
\hline 4 & $\begin{array}{l}\text { Jenis ikan } \\
\text { karang }\end{array}$ & 4 & $>100$ & 4 & $50-100$ & 3 & $20->50$ & 2 & $<20$ & 1 \\
\hline 5 & $\begin{array}{l}\text { Kecepatan } \\
\text { arus } \\
(\mathrm{cm} / \mathrm{det})\end{array}$ & 3 & $0-15$ & 4 & $>15-30$ & 3 & $>30-50$ & 2 & $>50$ & 1 \\
\hline 6 & $\begin{array}{l}\text { Kedalaman } \\
\text { terumbu } \\
\text { karang (m) }\end{array}$ & 3 & $6-15$ & 4 & $\begin{array}{c}>15-20 \\
>3-6\end{array}$ & 3 & $>20-30$ & 2 & $>30,<3$ & 1 \\
\hline
\end{tabular}

Sumber : Yulianda et al., (2010) 


\section{HASIL DAN PEMBAHASAN}

\subsection{Terumbu Karang}

Berdasarkan hasil penelitian ditemukan sebanyak 217 jenis karang batu yang termasuk dalam 52 genus dari 16 famili. Karang batu dari famili Acroporidae paling banyak ditemukan sekitar 63 spesies, selanjutnya famili Faviidae sebanyak 51 spesies dan famili Fungiidae sebanyak 25 spesies. Sedangkan untuk tingkat genus variasi spesies terbanyak adalah Acropora yaitu sebanyak 45 spesies, selanjutnya Montipora 15 spesies dan Favia sebanyak 13 spesies (Tabel 3).

Setiap lokasi penelitian memiliki dominasi jenis yang berbeda. Spesies yang mendominasi di Negeri Ameth yaitu Millepora dichotoma, Porites annae dan Pocillopora verrucosa. Negeri Akoon didominasi oleh jenis Porites lutea dan Porites lobata, Negeri Nahalia dan Negeri Sila didominasi oleh jenis Porites cylindrica dan Porites nigrescens. Negeri Titawaai didominasi oleh karang batu Porites lutea dan Favites abdita. Sedangkan Negeri Abubu didominasi oleh karang batu jenis Porites lutea, Pocillopora verrucosa serta Acropora hyacinthus.

Tabel 3. Keragaman taksa karang batu di Pulau Nusalaut.

\begin{tabular}{lccc}
\hline $\begin{array}{l}\text { Stasiun } \\
\text { Penelitian }\end{array}$ & $\begin{array}{c}\text { Jumlah } \\
\text { Suku }\end{array}$ & $\begin{array}{c}\text { Jumlah } \\
\text { Marga }\end{array}$ & $\begin{array}{c}\text { Jumlah } \\
\text { Jenis }\end{array}$ \\
\hline Negeri Ameth & 15 & 51 & 177 \\
Negeri Akoon & 13 & 41 & 111 \\
Negeri Nalahia & 15 & 43 & 118 \\
Negeri Sila & 14 & 46 & 141 \\
Negeri & 14 & 48 & 156 \\
Titawaai & & & \\
Negeri Abubu & 14 & 46 & 151 \\
\hline
\end{tabular}

Berdasarkan hasil analisis diperoleh nilai tutupan karang batu di ke-enam lokasi penelitian berkisar antara 58,54\%-77,00\% (Tabel 4). Sesuai kriteria penilaian, kondisi karang batu di lokasi penelitian berada dalam kategori "Baik" sampai "Sangat baik".

Tabel 4. Persentase komponen dasar di Lokasi Penelitian.

\begin{tabular}{lcccccc}
\hline \multirow{2}{*}{ Komponen Dasar } & Stasiun Penelitian \\
\cline { 2 - 7 } & Ameth & Akoon & Nalahia & Sila & Titawaii & Abubu \\
\hline Hard Coral & 77,00 & 58,54 & 66,28 & 73,84 & 74,38 & 73,96 \\
$\sim$ Acropora & 23,74 & 1,40 & 1,22 & 11,72 & 18,74 & 21,52 \\
$\sim$ Non-Acropora & 53,26 & 57,14 & 65,06 & 62,12 & 55,64 & 52,44 \\
Dead Coral & 8,26 & 25,78 & 11,70 & 5,92 & 6,16 & 14,50 \\
Algae & 0,00 & 0,00 & 0.00 & 0,00 & 0,00 & 0,00 \\
Other Fauna & 12,64 & 1,66 & 0,00 & 19,72 & 7,90 & 4,18 \\
Abiotic & 2,56 & 14,02 & 22,02 & 0,52 & 11,20 & 7,36 \\
Total & $100 \%$ & $100 \%$ & $100 \%$ & $100 \%$ & $100 \%$ & $100 \%$ \\
\hline
\end{tabular}

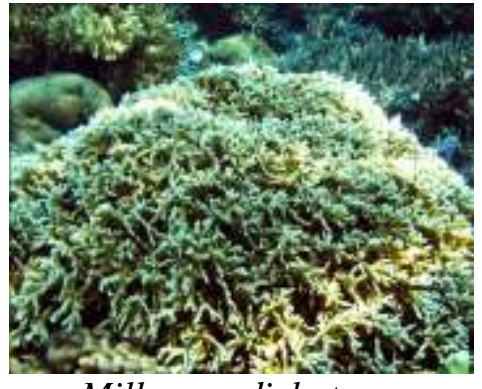

Millepora dichotoma

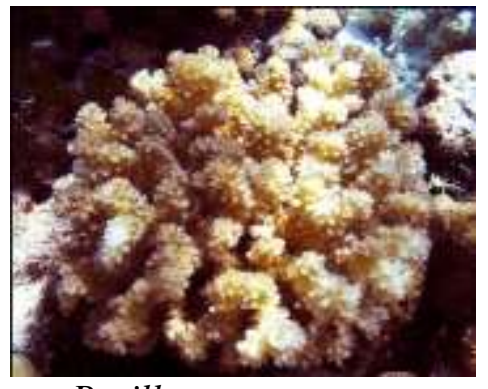

Pocillopora verrucosa

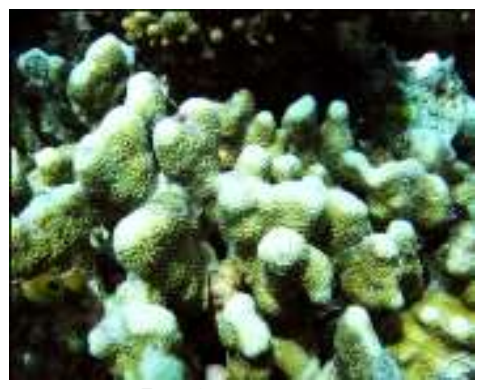

Porites annae 


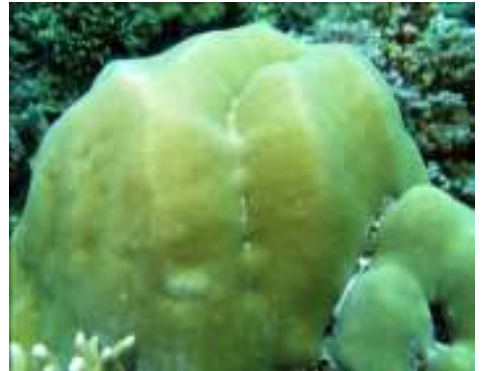

Porites lutea

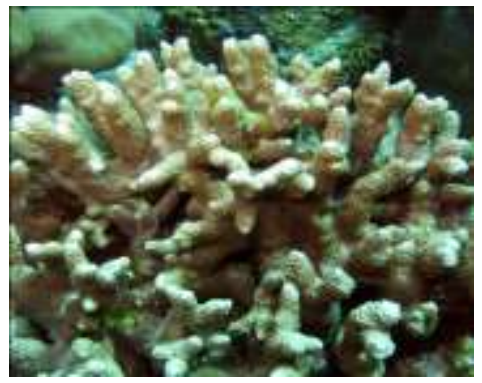

Porites nigrescens

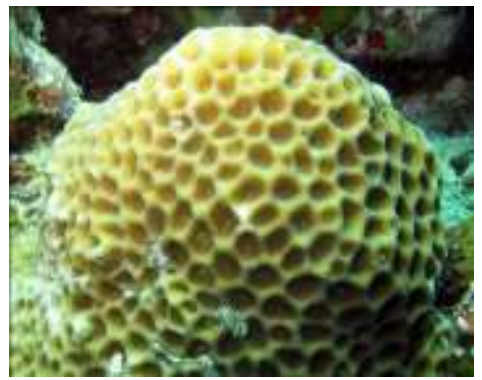

Favites abdita

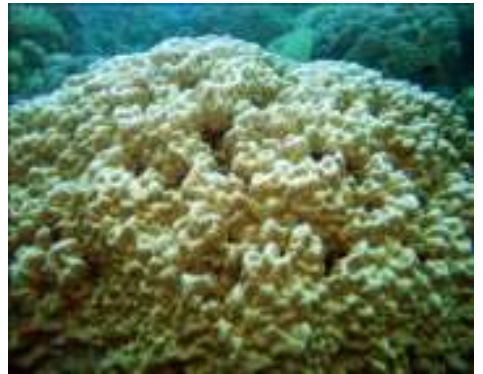

Porites lobata

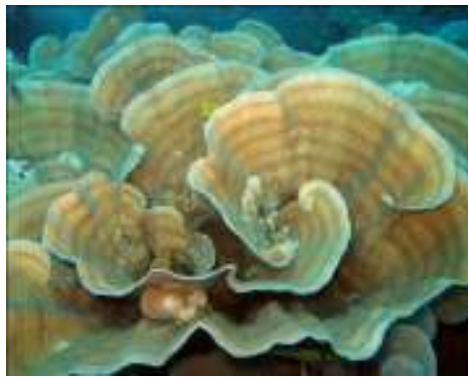

Turbinaria reniformis

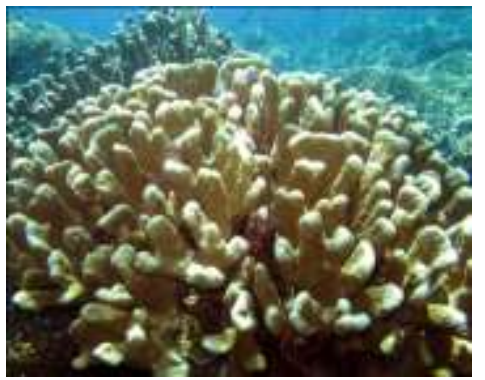

Acropora palifera

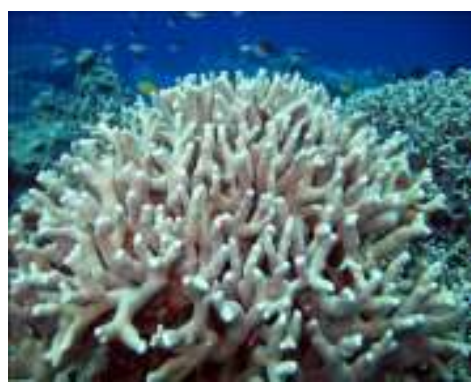

Porites cylindrica

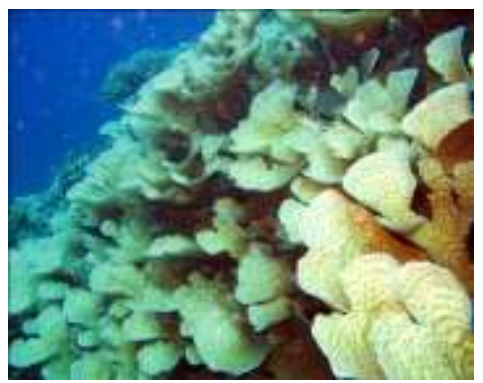

Echinopora lamellosa

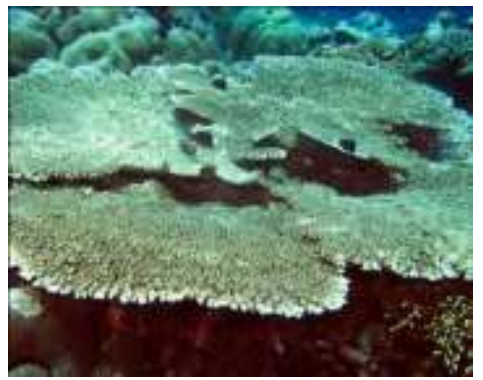

Acropora hyacinthus

Gambar 2. Jenis-jenis karang batu yang tumbuh mendominasi di stasiun penelitian Pulau Nusalaut.

\subsection{Ikan Karang}

Hasil pengamatan ikan karang pada enam lokasi penelitian terdapat total 2.838 individu yang terdiri dari 25 famili dan 170 jenis. Adapun pengelompokkan ikan karang pada penelitian ini dibagi menjadi tiga kategori berdasarkan peranannya, yaitu ikan indikator, ikan major dan ikan target (Amesbury and Myers, 1982, Dartnall and Jones, 1986, English et al., 1994).

Ikan yang termasuk dalam kelompok tersebut adalah yang dianggap berasosiasi paling kuat dengan karang. Kelompok ikan ini meliputi ikan kepe-kepe (Family: Chaetodontidae) yang terdiri atas beberapa genus yakni Chaetodon, Chelmon, Heniochus dan Forcipiger (Anderson et al., 1981, Harmelin-Vivien and BouchonNavaro, 1983, Pratchett et al., 2004). Jenis ikan di atas diketahui sebagai pemakan karang keras (hard coral), antara lain Chaetodon baronessa, Chaetodon lunulatus, Chaetodon trifascialis, Chaetodon plebeius dan Chaetodon rainfordi. Sedangkan jenis ikan lainnya, yaitu Chaetodon auriga, Chaetodon aureofasciatus, Chaetodon citrinellus, Chaetodon melannotus dan Chaetodon vagabundus, merupakan ikan yang tidak terlalu bergantung karang sebagai sumber makanan (Pratchett et al., 2006). 


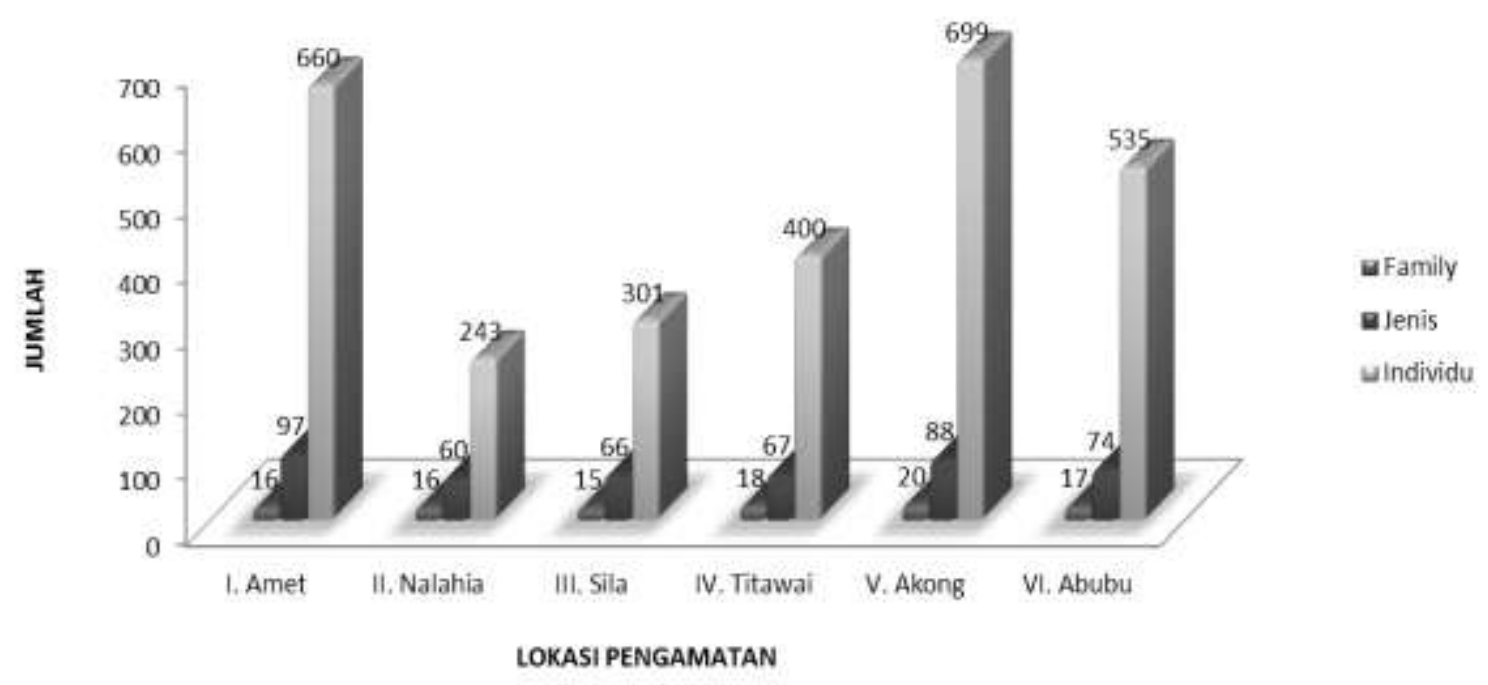

Gambar 3. Komposisi ikan karang yang diperoleh di Pulau Nusalaut.

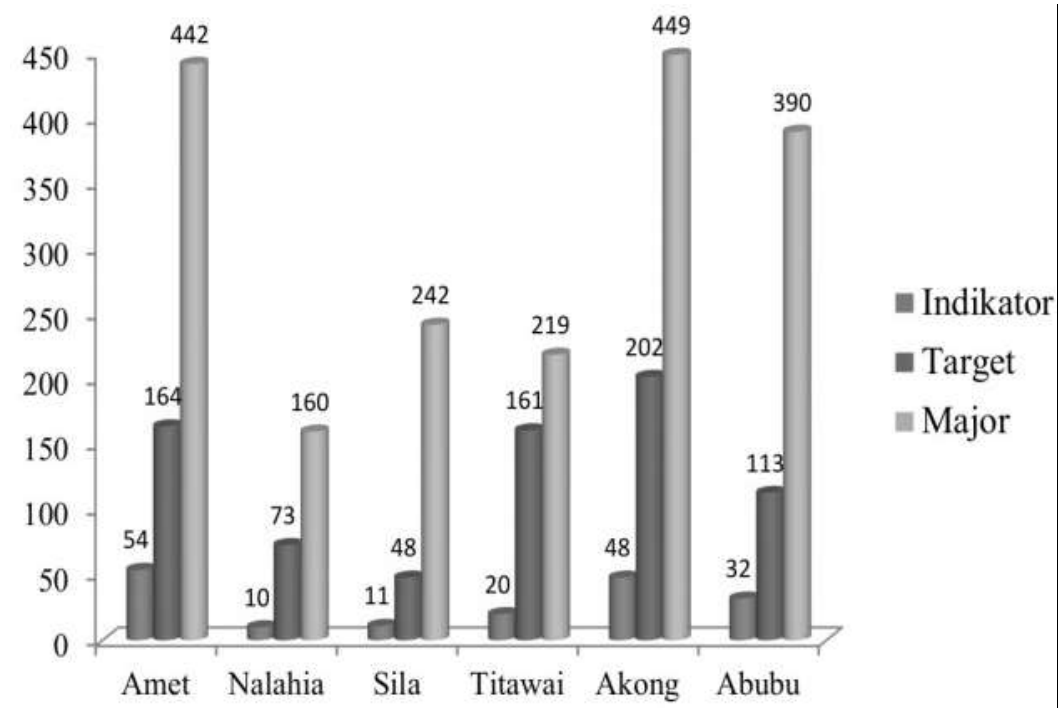

Gambar 4. Persentase dan kategori ikan karang yang diperoleh di Pulau Nusalaut.

Pada penelitian di Pulau Nusalaut ini, ditemukan 175 jenis ikan dari famili Chaetodontidae. Kelimpahan tertinggi berada di stasiun Ameth dengan 54 jenis, diikuti dengan stasiun Akoon 48 jenis, Abubu 32 jenis. Sedangkan kelimpahan terendah berada di stasiun Sila dan Nalahia dengan masingmasing 11 dan 10 jenis. Ikan kepe-kepe dapat diasosiasikan dengan kondisi kesehatan terumbu karang dimana penurunan kelimpahan jenis ikan ini dapat dijadikan peringatan awal akan penurunan kondisi terumbu karang (Hourigan et al., 1988, Crosby and Reese, 2005, Valavi et al., 2010). Ikan target adalah ikan-ikan yang dikonsumsi dan bernilai ekonomis penting. Mereka hidup berasosiasi dengan terumbu karang dan ditemukan sebanyak 761 jenis ikan terget yang berasal dari famili Lutjanidae, Serranidae, Siganidae di semua stasiun. Ikan-ikan tersebut banyak dikonsumsi oleh masyarakat dan mempunyai nama komersil yaitu ikan kakap, kerapu dan baronang. Pada umumnya ikan-ikan tersebut 
hidup soliter dan mudah dihitung jumlahnya. Adapun ikan target yang dijumpai dalam kelompok besar yaitu famili Caesionidae (ekor kuning), (Graham et al., 2005) menuturkan bahwa ikan-ikan dari famili ini sering dijumpai dalam kelompok besar. Ikan target lainnya yang ditemukan dan dikonsumsi oleh masyarakat berasal dari famili Acanthuridae, Carangidae, Letrinidae, Mullidae, Scaridae. Stasiun Akoon memiliki kelimpahan ikan target tertinggi yaitu 202 jenis, diikuti stasiun Ameth dan Titawaai masing-masing 164 dan 161 jenis. Kelimpahan terendah yaitu stasiun Sila dengan 48 jenis. Adapun jenis ikan yang mendominasi adalah Naso hexacanthus dengan jumlah 95 ekor. Ikan ini ada di semua stasiun kecuali stasiun Sila. Sedangkan jenis terendah adalah Seriola sp (Carangidae) dan Upeneus tragulla (Mullidae).

Ikan major merupakan kelompok ikan terbesar dari ikan penghuni terumbu karang, umumnya hidup dalam kelompok besar (schooling fish) misalnya ikan betok genus Pomacentrus, Dascyllus, Chromis dan Amblyglyphidodon dari famili Pomacentridae. Ikan-ikan yang termasuk dalam kelompok ini umumnya berukuran kecil (Permana, 1996). Penelitian ini telah menemukan sebanyak 1.902 ekor ikan major yang didominasi oleh Odonus niger (trigger fish) sebanyak 450 ekor. Jenis ikan ini sangat banyak ditemukan pada stasiun Akoon dan Abubu dengan masing-masing jumlah 200 ekor. Adapun stasiun yang memiliki kelimpahan tertinggi adalah stasiun Akoon dengan 449 jenis ikan.

Berdasarkan analisis keanekaragaman, ditemukan indeks keanekaragaman (H') berada pada kisaran 3,05-4,09. Berdasarkan kriteria, maka secara keseluruhan keanekaragaman ikan karang di pesisir pulau Nusalaut berada pada kondisi yang cukup baik. Indeks keanekaragaman menunjukkan kekayaan spesies dengan melihat jumlah spesies dalam suatu komunitas dan kelimpahan relatif. Suatu komunitas dikatakan mem-punyai keanekaragaman spesies tinggi jika kelimpahan spesies yang ada atau proporsi antar spesies secara keseluruhan sama banyak atau hampir sama jumlahnya (Brower et al., 1998). Dari penelitian diperoleh data bahwa stasiun Ameth memiliki tingkat keanekaragaman tertinggi $(4,088)$ dan terendah adalah stasiun Abubu $(3,046)$. Berdasarkan pengamatan di lapangan stasiun Ameth diketahui memiliki kondisi terumbu karang yang lebih baik dari stasiun Abubu. Stasiun Abubu berbatasan langsung dengan Laut Banda dengan karakteristik arus yang cukup deras.

Tabel 5. Hasil analisa biodiversitas ikan karang di Pulau Nusalaut.

\begin{tabular}{clccc}
\hline \multirow{2}{*}{ No } & Lokasi & \multicolumn{3}{c}{ DIVERSITY INDEX } \\
& Pengamatan & $\mathrm{H}^{\prime}$ & $\mathrm{D}$ & $\mathrm{e}$ \\
\hline 1. & Ameth & 4,0887 & 0,02505 & 0,89377 \\
& & 62585 & 0505 & 5061 \\
2. & Nalahia & 3,6814 & 0,03713 & 0,89915 \\
& & 49768 & 8648 & 4849 \\
3. & Sila & 3,4333 & 0,06171 & 0,81948 \\
& & 4236 & 0136 & 0977 \\
4. & Titawaai & 3,6697 & 0,03681 & 0,87277 \\
& & 46724 & 25 & 4078 \\
5. & Akoon & 3,4395 & 0,09729 & 0,76821 \\
& & 51162 & 6158 & 3629 \\
6. & Abubu & 3,0467 & 0,15289 & 0,70787 \\
& & 30387 & 7196 & 2749 \\
\hline
\end{tabular}

Indeks kemerataan atau sering disebut dengan indeks keseragaman (e) menunjukkan kestabilan sebuah komunitas. Nilai ini mengukur jumlah individu antar spesies dalam suatu komunitas dimana semakin merata penyebaran individu/ proporsi antar spesies, maka keseimbangan komunitas semakin meningkat. Umumnya apabila suatu komunitas memiliki nilai H' dan e tinggi, maka nilai dominansi (D)-nya cenderung rendah. Hasil analisis keaneka-ragaman ikan karang di Pulau Nusalaut menunjukkan bahwa indeks kemerataan (e) berada pada kisaran 0,71-0,89 yaitu me-nandakan kondisi komunitas yang stabil. Hasil ini diperkuat dengan nilai indeks dominansi (D) yang cenderung rendah $(0,025-0,152)$, yaitu menunjukkan tidak ada jenis yang dominasi, 
sehingga akan mengarah pada kondisi komunitas tidak tertekan (Masrizal dan Azhar, 2001).

\subsection{Kesesuaian Wisata}

Pulau Nusalaut merupakan salah satu pulau kecil dengan luas daratan 919,5 ha, yang jaraknya \pm 2 jam dengan me-nggunakan perahu motor dari Pulau Ambon, Ibukota Propinsi Maluku. Pulau Nusalaut merupakan gugus kepulauan Lease dan sudah terkenal sejak zaman penjajahan Belanda, dimana pulau ini merupakan salah satu tujuan bagi para pedagang khususnya pedagang rempahrempah terutama cengkih dan pala.

Berdasarkan hasil kesesuaian wisata snorkling seluruh lokasi penelitian dikategorikan "Sangat Sesuai" untuk wisata snorkling. Indeks kesesuaian wisata snorkling tertinggi yaitu Negeri Ameth 97,22\% sedangkan indeks kesesuaian wisata snorkling terendah yaitu Negeri Nalahia $81,48 \%$. Negeri Nalahia mempunyai lebar hamparan datar karang sempit yaitu sekitar $15 \mathrm{~m}$, sehingga menyebabkan skor untuk parameter ini rendah. Berbeda dengan keadaan di Negeri Ameth semua parameter memiliki skor sempurna kecuali parameter lebar hamparan datar karang, hanya mendapatkan skor 3. Lebar hamparan datar di Negeri Ameth sekitar 500 m. Untuk lebih jelasnya nilai indeks kesesuaian wisata snorkling dapat dilihat pada Tabel 6.

Meskipun perairan di pesisir Pulau Nusalaut sangat sesuai untuk di-kembangkan wisata bahari (terutama snorkling dan selam), perlu dipahami juga batasan dan daya dukung dari lingkungan agar kelestarian ekosistem terumbu karang tetap terjaga. Setidaknya $73,9 \%$ dari 353 penyelam melakukan kontak dengan karang yang menyebabkan kerusakan minor $79,8 \%$, moderat $49 \%$ dan mayor (patahan) $4,1 \%$ Barker et al. (2004). Selanjutnya, Hind et al. (2010) menyatakan bahwa 73\% kegiatan wisata menyelam merupakan ancaman serius untuk perikanan dimasa yang akan datang. Untuk tetap menjaga kelestarian lingkungan maka, kegiatan wisata bahari harus berpegang pada prinsip wisata berkelanjutan. Menurut Owen et al. (1993) wisata berkelanjutan adalah ketetapan dan prinsip pada keuntungan ekonomi jangka panjang, mendukung ter-hadap kebutuhan dan aspirasi masyarakat lokal, skala yang mengikuti karakter kawasan, pengakuan nilai intrinsik dari lingkungan dan keseimbangan antara aspek ekologi dan ekonomi. Yulianda et al. (2010), ekowisata adalah sebagai bentuk wisata yang menekankan tanggung jawab terhadap kelestarian sumberdaya alam, sehingga aspek ekologi merupakan prioritas utama yang harus diperhatikan dalam pengelolaannya.

Berdasarkan 6 (enam) parameter kesesuaian wisata selam, seluruh stasiun dikategorikan "Sangat Sesuai". Indeks kesesuaian wisata antara $81,25 \%$ sampai 95,83\%. Indeks tertinggi yaitu Negeri Ameth dan indeks terendah yaitu Negeri Akoon dan stasiun 3 Negeri Nalahia. Lebih jelasnya nilai indeks kesesuaian wisata selam dapat dilihat pada Tabel 7.

Tabel 6. Nilai indeks kesesuaian wisata snorkling.

\begin{tabular}{|c|c|c|c|c|c|c|c|c|c|c|c|c|c|c|}
\hline \multirow[t]{2}{*}{ No } & \multirow[t]{2}{*}{ Parameter } & \multirow[t]{2}{*}{ Bobot } & \multicolumn{2}{|c|}{$\begin{array}{l}\text { Negeri } \\
\text { Ameth }\end{array}$} & \multicolumn{2}{|c|}{$\begin{array}{l}\text { Negeri } \\
\text { Akoon }\end{array}$} & \multicolumn{2}{|c|}{$\begin{array}{c}\text { Negeri } \\
\text { Nalahia }\end{array}$} & \multicolumn{2}{|c|}{ Negeri Sila } & \multicolumn{2}{|c|}{$\begin{array}{c}\text { Negeri } \\
\text { Titawaai }\end{array}$} & \multicolumn{2}{|c|}{$\begin{array}{l}\text { Negeri } \\
\text { Abubu }\end{array}$} \\
\hline & & & Skor & $\mathrm{N}$ & Skor & $\mathrm{N}$ & Skor & $\mathrm{N}$ & Skor & $\mathrm{N}$ & Skor & $\mathrm{N}$ & Skor & $\mathrm{N}$ \\
\hline 1 & $\begin{array}{l}\text { Kecerahan } \\
\text { perairan }\end{array}$ & 5 & 4 & 20 & 3 & 15 & 3 & 15 & 4 & 20 & 4 & 20 & 4 & 20 \\
\hline 2 & $\begin{array}{l}\text { Tutupan } \\
\text { komunitas } \\
\text { karang }\end{array}$ & 5 & 4 & 20 & 3 & 15 & 3 & 15 & 3 & 15 & 3 & 15 & 3 & 15 \\
\hline 3 & $\begin{array}{l}\text { Jenis life- } \\
\text { form }\end{array}$ & 4 & 4 & 16 & 3 & 12 & 3 & 12 & 3 & 12 & 3 & 12 & 4 & 16 \\
\hline
\end{tabular}




\begin{tabular}{|c|c|c|c|c|c|c|c|c|c|c|c|c|c|c|}
\hline \multirow[t]{2}{*}{ No } & \multirow[t]{2}{*}{ Parameter } & \multirow[t]{2}{*}{ Bobot } & \multicolumn{2}{|c|}{$\begin{array}{l}\text { Negeri } \\
\text { Ameth }\end{array}$} & \multicolumn{2}{|c|}{$\begin{array}{l}\text { Negeri } \\
\text { Akoon }\end{array}$} & \multicolumn{2}{|c|}{$\begin{array}{c}\text { Negeri } \\
\text { Nalahia }\end{array}$} & \multicolumn{2}{|c|}{ Negeri Sila } & \multicolumn{2}{|c|}{$\begin{array}{c}\text { Negeri } \\
\text { Titawaai }\end{array}$} & \multicolumn{2}{|c|}{$\begin{array}{l}\text { Negeri } \\
\text { Abubu }\end{array}$} \\
\hline & & & Skor & $\mathrm{N}$ & Skor & $\mathrm{N}$ & Skor & $\mathrm{N}$ & Skor & $\mathrm{N}$ & Skor & $\mathrm{N}$ & Skor & $\mathrm{N}$ \\
\hline 4 & $\begin{array}{l}\text { Jenis ikan } \\
\text { karang }\end{array}$ & 4 & 4 & 16 & 4 & 16 & 4 & 16 & 4 & 16 & 4 & 16 & 4 & 16 \\
\hline 5 & $\begin{array}{l}\text { Kecepatan } \\
\text { arus }\end{array}$ & 3 & 4 & 12 & 4 & 12 & 4 & 12 & 3 & 9 & 4 & 12 & 4 & 12 \\
\hline 6 & $\begin{array}{l}\text { Kedalaman } \\
\text { terumbu } \\
\text { karang }\end{array}$ & 3 & 4 & 12 & 4 & 12 & 4 & 12 & 3 & 9 & 3 & 9 & 3 & 9 \\
\hline \multirow[t]{4}{*}{7} & $\begin{array}{l}\text { Lebar } \\
\text { hamparan } \\
\text { datar } \\
\text { karang }\end{array}$ & 3 & 3 & 9 & 3 & 9 & 2 & 6 & 3 & 9 & 3 & 9 & 3 & 9 \\
\hline & Total & & & 105 & & 91 & & 88 & & 90 & & 93 & & 97 \\
\hline & $\%$ & & & 97,22 & & 84,26 & & 81,48 & & 83,33 & & 86,11 & & 89,81 \\
\hline & & & & S1 & & S1 & & S1 & & S1 & & $\mathrm{S} 1$ & & S1 \\
\hline
\end{tabular}

Tabel 7. Nilai indeks kesesuaian wisata selam.

\begin{tabular}{|c|c|c|c|c|c|c|c|c|c|c|c|c|c|c|}
\hline \multirow[t]{2}{*}{ No } & \multirow{2}{*}{ Parameter } & \multirow{2}{*}{ Bobot } & \multicolumn{2}{|c|}{$\begin{array}{l}\text { Negeri } \\
\text { Ameth }\end{array}$} & \multicolumn{2}{|c|}{$\begin{array}{l}\text { Negeri } \\
\text { Akoon }\end{array}$} & \multicolumn{2}{|c|}{$\begin{array}{c}\text { Negeri } \\
\text { Nalahia }\end{array}$} & \multicolumn{2}{|c|}{ Negeri Sila } & \multicolumn{2}{|c|}{$\begin{array}{c}\text { Negeri } \\
\text { Titawaai }\end{array}$} & \multicolumn{2}{|c|}{$\begin{array}{l}\text { Negeri } \\
\text { Abubu }\end{array}$} \\
\hline & & & Skor & $\mathrm{N}$ & Skor & $\mathrm{N}$ & Skor & $\mathrm{N}$ & Skor & $\mathrm{N}$ & Skor & $\mathrm{N}$ & Skor & $\mathrm{N}$ \\
\hline 1 & $\begin{array}{l}\text { Kecerahan } \\
\text { perairan }\end{array}$ & 5 & 4 & 20 & 3 & 15 & 3 & 15 & 4 & 20 & 4 & 20 & 4 & 20 \\
\hline 2 & $\begin{array}{l}\text { Tutupan } \\
\text { komunitas } \\
\text { karang }\end{array}$ & 5 & 4 & 20 & 3 & 15 & 3 & 15 & 3 & 15 & 3 & 15 & 3 & 15 \\
\hline 3 & $\begin{array}{l}\text { Jenis life- } \\
\text { form }\end{array}$ & 4 & 4 & 16 & 3 & 12 & 3 & 12 & 3 & 12 & 3 & 12 & 4 & 16 \\
\hline 4 & $\begin{array}{l}\text { Jenis ikan } \\
\text { karang }\end{array}$ & 4 & 3 & 12 & 3 & 12 & 3 & 12 & 3 & 12 & 3 & 12 & 3 & 12 \\
\hline 5 & $\begin{array}{l}\text { Kecepatan } \\
\text { arus }\end{array}$ & 3 & 4 & 12 & 4 & 12 & 4 & 12 & 3 & 9 & 4 & 12 & 4 & 12 \\
\hline \multirow[t]{4}{*}{6} & $\begin{array}{l}\text { Kedalaman } \\
\text { terumbu } \\
\text { karang }\end{array}$ & 3 & 4 & 12 & 4 & 12 & 4 & 12 & 4 & 12 & 4 & 12 & 4 & 12 \\
\hline & Total & & & 92 & & 78 & & 78 & & 80 & & 83 & & 87 \\
\hline & $\%$ & & & 95,83 & & 81,25 & & 81,25 & & 83,33 & & 36,46 & & 90,62 \\
\hline & & & & $\mathrm{S} 1$ & & S1 & & S1 & & S1 & & S1 & & $\mathrm{S} 1$ \\
\hline
\end{tabular}

\section{KESIMPULAN}

Pesisir Pulau Nusalaut memiliki keanekaragaman terumbu karang dan ikan karang yang tinggi, sehingga berpotensi untuk dapat dikembangkan pada kegiatan wisata bahari. Hasil analisis menunjukan dari enam lokasi penelitian, semua dikategorikan sangat sesuai untuk kegiatan wisata snorkling dan selam.

\section{UCAPAN TERIMA KASIH}

Kami mengucapkan terima kasih kepada Kepala Pusat Penelitian Laut Dalam LIPI, yang telah memberikan dukungan terhadap pelaksanaan kegiatan penelitian ini. Ucapan terima kasih juga kami sampaikan kepada teman sejawat di Pusat Penelitian Laut Dalam dan seluruh pihak yang telah berpartisipasi dalam kegiatan penelitian ini. 


\section{DAFTAR PUSTAKA}

Ahmed, M., G.M. Umali, C.K. Chong, M.F. Rull, and M.C. Garcia. 2007. Valuing recreational and conservation benefits of coral reefs - The case of Bolinao, Philippines. Ocean and Coastal Management, 50: 103-118.

Alatalo, R.V. 1981. Problems in the measurement of evenness in ecology. Oikos, 37(2): 199-204. https://doi.org/10.2307/3544465

Allen, G.R., R. Steene, P. Humann, and N. DeLoach.2003. Reef fish identification: tropical Pacific., New World Publications Inc.Jacksonville, Australia.457 p.

Amesbury, S.S, and R.F. Myers. 1982. Guide to the coastal resources of Guam. $1^{\text {st }}$ ed. University of Guam Marine Laboratory.Guam.141 p.

Anderson, G., A. Ehrlich, P. Ehrlich, J. Roughgarden, B. Russell, and F. Talbot. 1981. The community structure of coral reef fishes. American Naturalist, 117(4): 476495.

https://doi.org/10.1086/283729

Barker, N.H., and C.M. Roberts. 2004. Scuba diver behavior and the management of diving impacts on coral reefs. Biologi Conservation, 120(4): 481489.

https://doi.org/10.1016/j.biocon.2004. 03.021

Bertels, L., T. Vanderstraete, S.V. Coillie, E. Knaeps, S. Strecks, R. Goossens, and B. Deronde. 2008. Mapping of coral reefs using hyperspectral CASI data; a case study: Fordata, Tanimbar, Indonesia. International J. of Remote Sensing, 29(8): 2359-2391. https://doi.org/10.1080/01431160701 408469

Brower, J.E., J.H. Zar, and C. von Ende. 1998. Field and laboratory methods for general ecology. WCB McGrawHill. Boston. 256 p.
Copper, P. 1994. Ancient reef ecosystem expansion and collapse. Coral Reefs, 13:3-11. https://doi.org/10.1007/BF00426428

Crosby, M.P., and E.S. Reese. 2005. Relationship of habitat stability and intra-specific population dynamics of an obligate corallivore butterflyfish. Aquatic Conservation: Marine and Freshwater Ecosystems, 15(S1): S13S25. https://doi.org/10.1002/aqc.697

Dartnall, A.J., and M.S. Jones. 1986. A manual of survey methods for living resources in coastal areas. Australian Institute of Marine Science \& ASEAN \& Australian Development Assistance Bureau.Townsville. 80 p.

English, S., C. Wilkinson, and V. Baker. 1994. Survey Manual For Tropical Marine Resources. ASEAN-Australia Marine Science Project, Living Coastal Resources. Townsville. 390 p.

Graham, N., N. Dulvy, S. Jennings, and N. Polunin. 2005. Size-spectra as indicators of the effects of fishing on coral reef fish assemblages. Coral Reefs, 24(1): 118-124. https://doi.org/10.1007/s00338-0040466-y

Harmelin-Vivien, M., and Y. BouchonNavaro. 1983. Feeding diets and significance of coral feeding among chaetodontid fishes in Moorea (French Polynesia). Coral Reefs, 2: 119-127. https://doi.org/10.1007/BF00000007

Hind, E.J., M.C. Hiponia, and T.S. Gray. 2010. From community-based to centralized for the governance of the marine protected area in Apo Island, Philippines?. Marine Policy, 34(1): 54-62.

https://doi.org/10.1016/j.marpol.2009. 04.011

Hourigan, T.F., C.T. Timothy, and E.S. Reese. 1988. Coral reef fishes as indicators of environmental stress in 
coral reefs. In: Marine organisms as indicators. Springer, 107-135.

https://doi.org/10.1007/978-1-46123752-5

Hughes, T.P., J.A. Harris, D.R. Bellwood, M. Card, S.R. Connolly, C. Folke, R. Grosberg, O. Hoegh-Guldeberg, D.R. Jackson, J. Kleypas, J.M. Lough, P. Marshall, M. Nyström, S.R. Palumbi, J.M.,Pandolfi, B. Rosen, and J. Roughgarden. 2003. Climate change, human impacts, and the resilience of coral reefs. Science, 301(5635): 929933.

https://doi.org/10.1126/science.10850 46

Kühlmann, D.H.H. 1988. The sensitivity of coral reefs to environmental pollution. Ambio, 17(1): 13-21.

Lembaga Ilmu Pengetahuan Indonesia (LIPI); COREMAP; CRITC. 2006. Manual monitoring kesehatan karang (reef health monitoring). LIPI. Jakarta. 109 p.

Masrizal dan Azhar. 2001. Kajian komunitas dan keanekaragaman jenis ikan pada ekosistem perairan sungai di Taman Nasional Kerinci Siblat. Pusat Studi Lingkungan Hidup, UNAND. Padang. 20 p.

Nybakken, J.W. 1992. Biologi laut: suatu pendekatan ekologis. (penterjemah). H.M. Edman, Koesoebiono, D. Bengen, M. Hutomo dan S. Sukarjo. PT. Gramedia. Jakarta. 480 p.

Newton, K., I.M. Cote, G.M. Pilling, S. Jennings and N.K. Dulvy. 2007. Current and future sustainability of island coral reef fisheries. Current Biology, 17(7): 655-658. https://doi.org/10.1016/j.cub.2007.02. 054

Odum, E.P. 1983. Basic ecology, Vol. 1, Saunders College Publishing. Philadelphia, Newyork. 320 p.

Permana, D.S. 1996. Potensi Wisata Bahari Pulau Mapor. LIPI. Jakarta. 30 p.
Peterson, C.H and J. Lubchenco. 1997. On the value of marine ecosystem to society. In. Daily, G.C. (Ed.), Nature's services. Societal dependence on natural ecosystems. Island Press. Newyork. 177-194.

Pratchett, M., S. Wilson, and A. Baird. 2006. Declines in the abundance of Chaetodon butterflyfishes following extensive coral depletion. J. of Fish Biology, 69(5): 1269-1280. https://doi.org/10.1111/j.10958649.2006.01161.x

Pratchett, M.S., S.K. Wilson, M.L. Berumen, and M.I. McCormick. 2004. Sublethal effects of coral bleaching on an obligate coral feeding butterflyfish. Coral Reefs, 23: 352-356. https://doi.org/10.1007/s00338-0040394-X

Smith, S.V. 1978. Coral-reef area and contribution of reefs to processes and resources of world's oceans. Nature, 273: 225-226. https://doi.org/10.1038/273225a0

Spalding, M.D., and A.M. Grenfell. 1997. New estimates of global and regional coral reef areas. Coral Reefs, 16(4): 225-230. https://doi.org/10.1007/s00338005007 8

Spurgeon, J.P.G. 1992. The economic valuation of coral reefs. Mar. Pollut. Bull, 24(11): 529-536.

https://doi.org/10.1016/0025326X(92)90704-A

Suharsono. 2008. Jenis-jenis Karang Indonesia. LIPI Press. Jakarta. 375p.

Susanto, A. Handoko, Suraji and T. Mutsunori. 2015. Management of coral reef ecosystems in Indonesia: Past, Present, and the Future. Coastal Ecosystems, 2: 21-41.

Valavi, H., A. Savari, V. Yavari, P. Kochanian, A. Safahieh, O.Sedighi. 2010. Coral reef anthropogenic impact bio-indicators in the northern part of the Persian Gulf. $J$. of 
Fisheries and Aquatic Science, 5(2): 70-81. https://doi.org/10.3923/jfas.2010.70.8 1

Veron, J. E. N. 1986. Corals Of Australia and The Indo-Pasific. University of Hawai Press. 656 p.

Wilkinson, C.E. 2000. Status of coral reefs of the world: 2000. Australian Institute of Marine Science (AIMS) and Global Coral Reef Monitoring Network (GCRMN). Townsville, Queensland. 388 p.

Wilkinson, C. E., C.M. Mohamad, S. Received : 24 January 2018

Sukarno and S. Sudara. 1992. A Reviewed : 29 April 2018

Regional Approach to Monitoring Accepted : 25 November 2019 by Asean-Australia Living Resources Projct. Proceeding of 7 th International Coral Reef Symposium, Guam 22-27 June, 1:138-143 p. Yulianda, F., A. Fahrudin, L. Adrianto, A.A. Hutabarat, S. Harteti, Kusharjani danH.S. Kang. 2010. Kebijakan konservasi perairan laut dan nilai valuasi ekonomi. Pusdiklat Kehutanan RI dan Secem Korea International Cooperation Agency. Bogor. 113 p. 